\title{
14 The Qin and Han Economies in Modern Chinese and Japanese Historiographies
}

\section{Introduction}

The late nineteenth and early twentieth centuries witnessed some fundamental changes in the East Asian world, not only in terms of political, institutional, societal, and economic aspects, but also of historiography. The defeat of China by the Western powers during the two Opium Wars (1839-1842 and 1856-1860) shocked the entire East Asian world. Some Chinese politicians and intellectuals began to realize the urgent need for reform. The Westernization Movement (also known as the Self-Strengthening Movement) which took place from 1861 to 1895 , covering aspects such as diplomacy, military, and industrial production, was a response to the challenges posed by Western powers. However, the movement eventually ended in the Sino-Japanese War with the defeat of China in 1895, which seemed to suggest that Japan was more successful in its modernization scheme than China. One of the results of this war was the shift in intellectual and cultural exchange between China and Japan.

China had long been the cultural center of the East Asian World and deemed a model by its neighbors, such as Japan and Korea. Already in the seventh century, Japan had developed a tradition of kundoku 訓読 ('reading by gloss'), which combines reading and translation of Chinese texts into a single integrated act. The early Japanese could use this method to comprehend Chinese texts as well as produce new texts. ${ }^{1}$ During the Tokugawa 徳川 period (1600-1868), kangaku 漢学 (Chinese learning), which was mainly based on Confucian ( $r u$ 儒) learning, had formed the basis of the mainstream ideology among the educated in Japan. Although the defeat of China during the Opium Wars greatly surprised the Japanese, it did not stop them from learning from the Chinese and absorbing Western knowledge through Chinese works. A significant shift in intellectual and cultural exchange between these two countries occurred after the defeat of China during the Sino-Japanese War. Many Chinese intellectuals turned to see the 'modernized' Japan as their new model. ${ }^{2} \mathrm{New}$ ideas and terminologies from the West flooded into China through the translations

\footnotetext{
1 Lurie defines kundoku as a complex of practices that "associate logographs of Chinese origin with Japanese words and transpose the resulting words into Japanese order while adding necessary grammatical elements, thereby producing an actual or imagined vocalization in Japanese” (2011, 175).

2 See Wang 2003; Chen 2007 for this background.
}

Note: I am grateful to Kwok-leong Tang for his helpful comments.

Ә Open Access. (c) 2020 Tsang Wing Ma, published by De Gruyter. (c) BY-NC-ND This work is licensed under the Creative Commons Attribution-NonCommercial-NoDerivatives 4.0 License.

https://doi.org/10.1515/9783110607741-023 
of Japanese work. The Western concepts of 'economy' and 'history', which were translated in Japanese as keizai 経済 and rekishi 歴史, were introduced to China along with this flood. ${ }^{3}$

From the early twentieth century on, the study of Chinese history in China and Japan had undergone several changes as responses to the contemporary political and intellectual environment. The aim of this chapter is not to offer a comprehensive literature review of modern scholarship on Qin 秦 and Han 漢 (221 BCE-220 CE) economic history, ${ }^{4}$ which is almost an impossible task given the limited length of this chapter, but rather to contextualize the writing of Qin and Han economic history in the development of modern Chinese and Japanese historiographies, so as to show the changes of concerns and methodologies in this field. Part one situates the studies of Chinese economic history in the transformations of Chinese and Japanese historiographies at the turn of the twentieth century. Part two examines the studies of Qin and Han socioeconomic history under Chinese Marxist historiography. Part three discusses the publishing of the Food and Commodities Semimonthly (Shihuo banyuekan 食貨半月刊) and the development of Qin and Han economic history in Taiwan and Hong Kong. The chapter concludes with a section introducing the new trends in the studies of early Chinese economy which are due mainly to the remarkable growth of the discoveries of ancient texts in recent decades.

\section{Transformations of Historiographies: Xin shixue (New Historiography) in China and Tōyōshi (Eastern History) in Japan}

After the defeat of China during the Sino-Japanese War, Chinese intellectuals realized that they needed a more comprehensive reform, which gave rise to the Hundred Days' Reform in 1898. Although the reform only lasted for about one hundred days due to factors including the internal conflict among the imperial families, it urged

3 Masini 1993, 183, 186. Both of these compounds were originally Chinese (jingji 經濟 and lishi 歷史 ) and later assimilated into the Japanese writing system. In classical Chinese, jingii is an abbreviation of jingshi jimin 經世濟民 ('to manage the realm and save the people') while lishi refers to lidai zhi shi 歷代之史 ('history of different dynasties'). When the concepts of 'economy' and 'history' were introduced to Japan, just as other Western concepts, the Japanese chose to use kanbun 漢文 ('Chinese writing') to translate them. Mehl 2000, 53 indicates that the Japanese during the Meiji era considered kanbun a language of the educated people and it was clearer and more concise in translating foreign language work.

4 There are several literature reviews which can serve this purpose. See Li 1999 for a general review on ancient Chinese economic history; Yamada 1993, 15-26 for Qin and Han fiscal history; Zhang 2006, 10-23 for Han settlements and cities; Kakinuma 2011, 3-39 for early Chinese monetization, etc. 
Chinese intellectuals to reconsider the practical function of traditional Chinese historiography in the face of threats by the Western powers. On the contrary, the war made the Japanese aware of their achievement in the Westernization movement and led to the rise of Japanese imperialism. Along with these changes came the transformation of Chinese studies from kangaku ('Chinese learning') to tōyōshi 東洋史 ('Eastern history') in Japan. The following considers two prominent figures in modern Chinese and Japanese historiographies, Liang Qichao 梁啟超 (1873-1929) and Katō Shigeshi 加藤繁 (1880-1946), to demonstrate the changes regarding concerns and methodologies in the writing of Chinese economic history.

In 1902, Liang Qichao’s famous essay “New Historiography” (Xin shixue 新史學) was serialized in the New Citizen Journal (Xinmin congbao 新民叢報), which formally launched an attack on the traditional Chinese historiography. As one of the leaders of the Hundred Days' Reform, Liang was exiled to Japan after the failure of the reform. Inspired by Western historiography, Liang criticized that the Chinese traditional historical writings, which are mainly presented in the annalistic and biographical styles, had four problems: Firstly, they only paid attention to the imperial courts but not the entire nation, thus the so-called 'Twenty-Four Standard Histories' (ershisi shi 二十四史) were not 'history' but nothing more than the history of 24 imperial houses. Secondly, they only focused on prominent figures, but not the people as a group. Thirdly, they emphasized ancient times rather than modern times. Fourthly, they merely narrated facts but did not study historical causality, thus offered no meaningful advice for the need of present issues. ${ }^{5}$ Modern historians consider Liang Qichao's criticism of traditional Chinese historiography as a 'revolution' in modern Chinese historiography, which redefined the meaning of 'history." 6

In fact, the advocate of "New Historiography" also influenced the writing of economic history. Liang was one of the first Chinese scholars during his time who were aware of Western economic studies. He himself had written an essay titled " $\mathrm{A}$ Brief History of the Origin and Changes of Economic Studies" (Shengji xue xueshuo yange xiaoshi 生計學學說沿革小史). ${ }^{7}$ In “New Historiography,” he criticized that traditional Chinese historiography concentrated on political history and failed to develop other fields of history such as literary, ethnic, economic, and religious history. ${ }^{8}$ Since Ban Gu's 班固 introduction of “Treatise on Food and Commodities" (Shihuo zhi 食貨志) in the History of the Han (Hanshu 漢書), Chinese official historians adopted this genre of historical writing to record economic matters and included it in the official compiled history. The term shihuo ('food and commodities') was commonly

5 Liang 1926, 34.25b-28a. For analyses of Liang's historical ideas, see Xu 2003, 9-60; Wang 2001, $42-50$.

6 Xu 2003, 9-60.

7 Liang 1926.

8 Liang 1926, 34.29b. Liang's knowledge of Western economic studies was acquired through Japanese translations. Masini 1993, 183 points out that he was familiar with the meaning of the Japanese term keizai ('economy'). 
used as one of the general terms referring to economic matters in historical writings during the imperial period. ${ }^{9}$ Yet such a genre was not scholarly research of economic history in the modern sense but merely represented the dynastic views on economic policies and activities. During the twentieth century, an apparent change in the writing of economic history occurred, in which Chinese historians stopped following the traditional genre of "Treatise on Food and Commodities" and assimilated the Japanese translation of the Western concept of economy into the writing of economic history, the so-called jingji shi 經濟史 in Chinese. It might not be a direct result of Liang's advocacy of "New Historiography," but it had undoubtedly urged scholars to reevaluate the value of traditional Chinese historiography when facing the challenges posed by Western powers.

As most scholars have indicated, Liang's Japanese experience had a clear influence on his historical ideas. ${ }^{10}$ In fact, the most influential work on Qin and Han economic history during the early twentieth century was completed by Japanese scholars, of whom Katō Shigeshi was a pioneer in this field. Unlike China, Japan had been aware of Western knowledge since the Tokugawa period, during which the study of Western knowledge had formed an independent field called rangaku 蘭学 ('Dutch learning'). ${ }^{11}$ Since the Meiji 明治 restoration in 1868 until the SinoJapanese War in 1895, Japan had undergone a more comprehensive Westernization movement than China. The defeat of China signified the success of this movement and gave rise to Japanese imperialism during the late nineteenth and early twentieth centuries. In the meantime, the discipline of Chinese studies in Japan had also transformed from kangaku ('Chinese learning') to tōyōshi ('Eastern history'). ${ }^{12}$ Regarding this transformation, Margaret Mehl describes the following: "While kangaku was based on the assumption that China was the source of civilization, tôyōshi

9 Ban Gu elaborated the terms shi (food) and huo (commodities) as such: "The former may be said to be the excellent grains and [other] edibles produced by the agriculturalists. The latter may be defined as textiles, woven of vegetable fibers and of silk, of which wearing apparel can be made; as well as metals, knife [money], tortoise shells, cowries [etc.], with which wealth may be divided, benefits distributed, and [what the people] have exchanged for [what they] have not” 食謂農殖嘉 穀可食之物, 貨謂布帛可衣, 及金刀鬼貝, 所以分財布利通有無者也 (Hanshu 24a.1117, trans. Swann 1950, 109-10).

10 For example, Q. Edward Wang argues that Meiji intellectual Fukuzawa Yukichi's 福沢諭吉 (1835-1901) advocacy of 'histories of civilization' (bummeishiron 文明史論) provided a new perspective for Liang to understand Chinese history, see Wang 2001; 2003.

11 The Dutch were the only Westerners who were allowed to enter Japan during the Tokugawa period and they also became the only channel for the Japanese to learn about the West. See Katagiri 1982 for more on rangaku.

12 Many scholars including Katō himself attribute the founding of tōyōshi to Naka Michiyo 那珂通世 (1851-1908), who proposed to divide world history in the middle school curriculum into seiyōshi 西洋史 ('Western history') and tōyōshi in 1894 (Katō 1948, 50). The study of kokushi 国史 ('Japanese national history') was an independent discipline which does not belong to either seiyōshi or tōyōshi. 
recognized indebtedness to China, but also claimed Japanese superiority over contemporary China." ${ }^{13}$ Compared to kangaku scholars, tōyōshi scholars incorporated the traditional training of kangaku and Western methodologies in studying China. ${ }^{14}$ Born in 1880, Katō Shigeshi grew up along with this transformation. ${ }^{15}$ His studies of Chinese economic history demonstrate his training in both the kangaku and tōyōshi traditions.

While Qing kaojuxue 考據學 ('evidential research') formed Katō Shigeshi's fundamental knowledge of Chinese texts, ${ }^{16}$ his education of Western historiographies, such as Leopold von Ranke's (1795-1886) objective writing of history, differentiated him from the traditional kangaku scholars. As a son of a family with samurai antecedents during the Meiji period, Katō followed the path of his contemporaries and received the typical kangaku education when he was young. ${ }^{17}$ Katō then entered into the Tokyo Imperial University 東京帝国大学 (the modern-day University of Tokyo 東京大学) and studied Shina ('Chinese') History 支那史學科 with the first generation of tōyōshi scholars, including Naka Michiyo and Shiratori Kurakichi 白鳥庫吉 (1865-1942). ${ }^{18}$ From 1918 to 1919, Katō’s influential essay on Han fiscal history, titled "The Distinction of the State Finances and the Imperial House Finances during the Han Dynasty and a Look at the Imperial House Finance" (Kandai ni okeru kokka zaisei to teishitsu zaisei to no kubetsu name ni teishitsu zaisei ippan 漢代に於ける 国家財政と帝室財政との区別並に帝室財政一斑), was serialized in the Journal of Eastern Studies (Tōyō gakuhō 東洋学報). Adopting the contemporary terminologies kokka 国家 ('state') and teishitsu 帝室 ('imperial household'), Katō argued that the Western Han treasury was divided into two parts, treasury of the state and treasury of the imperial household, which were operated by different government agencies. He closely examined the incomes and expenses of the state's and imperial house's treasuries and investigated the abolishment of the imperial household's treasury during the reign of Emperor Guangwu 光武 (r. 25-57). This research explored the public and private spheres of the financial administration during the Western Han period. Despite being challenged and supplemented by contemporary and later scholars,

13 Mehl 2000, 64.

14 Mehl adds: "Perhaps more importantly, they lacked the reverence for China as the source of all learning, and their studies were separated from moral training” (2000, 64).

15 For academic biographies of Katō Shigeshi, see Katō 1948, 145-237; Egami 2015, 145-51.

16 Kaоjuxue ('evidential research') was the dominant academic discipline during the Qing period (1644-1912). Kaojuxue scholars emphasized an empirical approach, which was based on philology and textual criticism, in studying classical knowledge. Many Meiji kangaku scholars had been deeply influenced by this empirical approach. See Elman 2011 for more on Qing kaojuxue.

17 Mehl 2000, 61 points out that kangaku was regarded as the hallmark of good education during Meiji Japan compared to classical education in Europe.

18 Shiratori had studied with Ludwig Rieß (1861-1928), who was a student of Leopold von Ranke, at the Tokyo Imperial University. In an unfinished article on the methodology of Chinese economic history, Katō also showed that he was familiar with European economic terminologies and history (Katō 1948, 13-26). 
Katō's view formed the foundation of the studies of early Chinese economic history in Japanese scholarship. ${ }^{19}$

Katō's other works on Qin and Han economic history include essays on the ancient Chinese land system, Han poll tax and coinages, and annotated translations of the two most important transmitted texts on early Chinese economy - "Treatise on the Balanced Standard” (Pingzhun shu 平準書) of the Grand Scribes' Records (Shiji 史記) and “Treatise on Food and Commodities" of the History of Han. ${ }^{20}$ As shown in Yamada Katsuyoshi's 山田勝芳 (b. 1944) review, Katō’s attention paid to Han fiscal history has left apparent imprints on the work achieved by later scholars including Miyazaki Ichisada 宮崎市定 (1901-1995), Hiranaka Reiji 平中苓次 (1907-1973), Masubuchi Tatsuo 増淵龍夫 (1916-1983), Yoshinami Takashi 好並隆司 (1929-2010), and Yamada himself. ${ }^{21}$ Katō's influence in the writing of early Chinese economic history had already spread to the Chinese academic circle during the first half of the twentieth century. Early in the 1930s, Katō's argument for the division of the state and imperial household finances had been cited by Chinese scholars such as Zhou Yunxi 周等溪. ${ }^{22}$ Katō's essays on early Chinese economic history are included in the first volume of his book Shina keizaishi kōshō 支那經濟史考證, which was translated by $\mathrm{Wu}$ Jie 吳杰 into Chinese in 1959, just a few years after it was published in Japan. ${ }^{23}$

Since Katō's pioneering work in early Chinese economic history, Japanese scholars continued to make remarkable contributions to the field. Apart from the names mentioned above, Hamaguchi Shigekuni 浜口重国 (1901-81) clarified the conflicting records about the practice of Han labor service in transmitted texts, which was later proved mostly correct by Hirose Kunio 広瀬薰雄 (b. 1975) with the help of newly excavated texts in 2010. ${ }^{24}$ Utsunomiya Kiyoyoshi's 宇都宮清吉 (1905-98) detailed analysis of The Contract for a Youth (Tongyue 僮約) text reveals the manor economy of the southwestern region during the first century всE. ${ }^{25}$ Nishijima Sadao 西嶋定生 (1919-1998) offered a comprehensive account on Western Han social and economic history, which is still one of the works most accessible in the West. ${ }^{26}$ Other important works include Watanabe Shinichirō 渡邊信一郎 (b. 1949) on Han financial logis-

19 This long essay was later revised and included in Katō 1952-1953, 1: 35-156.

20 Katō 1942.

21 Yamada 1993, 15-26.

22 Zhou 1936, 8-9.

23 Katō 1959.

24 Hamaguchi 1966, 459-486; Hirose 2010, 269-332.

25 Utsunomiya 1955, 256-374. For an English translation of The Contract for a Youth, see Wilbur 1943, 383-92.

26 This study is included in the Qin and Han volume of The Cambridge History of China. Note that Nishijima's chapter in that volume is a translation of his Japanese essay written in 1967. A revised Japanese version of Nishijima's essay had already been incorporated into his book published in 1981 whereas the English translation based on the old Japanese version came out in 1986 due to the delay of the publishing of the Qin and Han volume; Nishijima 1981; 1986. 
tics and labor forces, Shigechika Keiju 重近啓樹 (b. 1951) on Qin and Han taxation and labor service system, Sahara Yasuo 佐原康夫 (b. 1958) on Han cities and markets, and most recently, Kakinuma Yōhei 柿沼陽平 (b. 1980) on early Chinese monetization. $^{27}$

\section{The Study of the Qin and Han Socioeconomic History under Chinese Marxist Historiography}

The flourishing of economic history writing in China, however, had to wait until the 1920s-1930s. From 1928 to 1933, many Chinese activists and historians participated in a debate on Chinese social history under Karl Marx's (1818-1883) economic model, the so-called 'Chinese social history controversy' (Zhongguo shehui shi lunzhan 中國社會史論戰). ${ }^{28}$ Although this debate was given credit for the rise of socioeconomic history (shehui jingji shi 社會經濟史) in China, it had been criticized that it had generated a trend of historical interpretation which assumed that the Europeanexperience-based Marxist theory was universally true and tailored Chinese historical materials to fit into the Marxist model. ${ }^{29}$ Such a trend became more dominant after the establishment of the People's Republic of China (PRC) in 1949; since then, Marxism has become the orthodox ideology in China. Chairman Mao Zedong 毛澤東 (1893-1976) stated clearly that historians should follow Marxist-Leninist models to study Chinese history. ${ }^{30}$ The studies of Chinese history in mainland China were therefore closely related to politics, a trend that reached its peak during the Cultural Revolution (1966-1976). Chinese historians who were engaged in the studies of Qin and Han economic history would inevitably have to respond to the questions regarding the placement of Qin and Han society in the Marxist model.

Marxist theory arrived in China in the late 1890s, but it did not receive wide attention among Chinese intellectuals until the late 1910s. Inspired by the Russian Revolution in 1917, discussion on Marxist theory and its application to Chinese history flourished through the introduction by Chen Duxiu 陳獨秀 (1879-1942) and Li Dazhao 李大釗 (1889-1927) in the magazine New Youth 新青年 (Xin qingnian) during the New Culture Movement. ${ }^{31}$ In searching for a new strategy in confronting the Nationalists (guomindang 國民黨), the nature of Chinese society under the Marxist model became a hotly debated topic among the Communists (gongchandang 共產黨)

27 Watanabe 2010; Shigechika 1999; Sahara 2002; Kakinuma 2011.

28 He 1937; Dirlik 1978; Lu 1979.

29 Dirlik 1978; Lu 1979.

30 Lu 1979, 29.

31 Japanese work on Marxist theory had served as the conduit through which Chinese intellectuals acquired their knowledge of Marxist theory (Dirlik 1978, 21). 
after 1927.32 From 1931 to 1933, the Reading Magazine (Dushu zazhi 讀書雜誌) published four special volumes on the topic 'Chinese social history controversy,' discussing how to correctly understand Marxist theory and properly apply the Marxist fivestage model (namely, primitive, slave, feudal, bourgeois, and socialist societies) to the development of Chinese history. ${ }^{33}$ Arif Dirlik argued that it caused a paradigm shift in the interpretation of historical changes in China: "Where previous historians had marked time according to political (whether individual, dynastic, or institutional) or intellectual changes, Marxist historians turned to transformations in the socioeconomic structure as the criteria for determining significant historical change." 34 The debate on Chinese social history in the 1930s did not reach a consensus and continued with another controversy on the periodization of ancient Chinese history in the 1950s. ${ }^{35}$ Many Marxist historians including Guo Moruo 郭沫若 (1892-1978), Fan Wenlan 范文瀾 (1893-1969), Jian Bozan 翦伯贊 (1898-1968), Lü Zhenyu 呂振羽 (19001980) and Hou Wailu 侯外盧 (1903-1987) had participated in the 1950s discussion. ${ }^{36}$

Regarding the placement of Qin and Han society in the Marxist model, the discussion centered on whether it was in the stages of feudal or slave society. Despite the diverse opinions of the periodization of Chinese history, participants of the debate generally agreed that the Chinese feudal society was based on a self-sufficient natural economy, while the money economy was the driving force leading to the destruction of this feudal society. The problem was determining when this feudal stage began. ${ }^{37}$ In 1958, Guo Moruo's periodization finally gained official recognition. The Ministry of Education of the PRC government adopted Guo's periodization in the higher education curriculum. He argued that the transition from the Spring and Autumn (771-476 BCE) to Warring States (475-221 BC) periods was the turning point of Chinese society, transforming from a slave to a feudal society. ${ }^{38}$ This periodization implied that the feudal stage lasted throughout the entire Chinese imperial period without any significant changes. To claim the political legitimacy of this view, Guo referred to a quote from Chairman Mao: "China was [in the stage of] a feudal society since the Zhou-Qin period” 自周秦以來, 中國是一個封建社會. ${ }^{39}$ In Guo’s interpretation, 'Zhou-Qin' refers to the transition from Zhou to Qin periods, which is around 475 BCE. ${ }^{40}$

32 Lu 1979; Dirlik 1978; Liang 2003 for more on this background.

33 Wang and $\mathrm{Lu} 1990$.

34 Dirlik 1978, 9.

35 Lu 1979, 141-166.

36 Li 1999, 131.

37 Liang 2005, 11-12.

$38 \mathrm{Lu}$ 1979, 7; He 2006, 2930-2939.

39 Guo 1954, 13.

40 Guo's views on the transition period from slave to feudal societies had changed several times, from around 770 BCE, to 206 BCE, to 475 BCE (Guo 1954, 2). 
Guo's periodization by no means represented a scholarly consensus on this issue, ${ }^{41}$ but since then most studies on Chinese socioeconomic history in mainland China labeled Qin and Han society as a feudal society. Two multivolume works on Chinese economic history, with the same title, Socioeconomic History of Feudal China (Zhongguo fengjian shehui jingji shi 中國封建社會經濟史), both refer Qin and Han society to the feudal stage in the Marxist model, even though they have different opinions on the beginning of the feudal society in Chinese history. ${ }^{42}$ Such a view was readdressed in a nine-volume government-sponsored work on Chinese economic history published in 1999, in which the chief editor Lin Ganquan 林甘泉 (19312017), a Marxist historian who specialized in Qin and Han economic history, rejected the idea that Qin and Han societies was still in the stage of a slave society. Incorporating newly excavated texts in recent decades, Lin distinguished convicted laborers from government-owned slaves and attested that the latter were only rarely engaged in large-scale agricultural production. According to his analysis, the major producers in the Qin and Han society were no longer slaves but peasants, who served an exploitative class of landlords as tenants and hired laborers. ${ }^{43}$ This view appears to be consistent with that proposed by Guo Moruo in the 1950s. ${ }^{44}$

The influence of the Marxist interpretation of history in modern Chinese historiography is profound and long-lasting. After the enthronement of Marxism as the orthodox ideology of the PRC government, Marxist writings replaced Confucian classics to become the new canons for scholars to seek for authority. A. F. P. Hulsewé observed that "Although the true scholar has recognized certain historical phenomena to be sui generis, he still finds himself compelled to find the right passage in the canon which should be applied in this particular case." 45 Chinese Marxist concepts such as historical materialism, production modes, feudal land ownership, and class struggle became indispensable analytical tools in studying Qin and Han economic history. Yet it does not mean that no real progress was made in this field. For example, Li Jiannong’s 李劍農 (1880-1963) comprehensive treatment of the Qin and Han economic history, Peng Xinwei’s 彭信威 (1908-1967) historical overview of Chinese

41 Other propositions include those which argued that the feudal society started during: 1 . the Western Zhou (ca. 1045-771 BCE) (Fan Wenlan); 2. the Qin-Han transition (Hou Wailu); 3. the Wei 魏 period (220-265 CE) (Tong Shuye 童書業 [1908-1968]). For various ideas on the periodization of Chinese history, see Lu 1979, 141-166.

42 While Fu 1981-1989 considers the Western Zhou as the beginning of the feudal society, Tian and Qi 1996 refers the Warring State period to the beginning of the feudal stage in China.

43 Lin 1999, 85-106.

44 Guo 1954. Note that the debate on the periodization of Chinese history also existed in postwar Japan as a response to the failure of Japanese imperialism. The debate had mainly divided into two camps, one was composed of scholars based at Kyoto University 京都大学 and one was at the University of Tokyo. Most members of these camps considered the Qin and Han periods as the ancient period of Chinese history, despite holding different views regarding the end of this period, Gao 1986. For an English account of this debate, see Tanigawa 1985, part 1.

45 Hulsewé 1968, 120. 
currencies, and Sun Yutang's 孫毓棠 (1911-1985) essays on Han textile industry and military service are still the foundation in the modern scholarship of early Chinese economy. ${ }^{46}$

As will be addressed in the following section, participants of the 'Chinese social history controversy' in the 1930s had already noticed the problems inherent in mechanically applying the Marxist model to Chinese history. Even after 1949, when Marxist theory became the orthodox ideology in China, some scholars such as Chen Zhi 陳直 (1901-1980) continued to follow an empirical approach to study Qin and Han economic history. ${ }^{47}$ This empirical approach was revived after the late 1970 s when the PRC's government shifted the focus from politics to economy. Many historians turned to a more evidence-based research approach while still adopting a Marxist framework. To name a few examples, Huang Jinyan 黃今言 (b. 1937) provided a comprehensive understanding of the Qin and Han taxation and labor service system; ${ }^{48}$ Zhang Jinguang's 張金光 (1936-2013) study of the Qin institutional history covered aspects including the land system, taxation, labor- and household system, all of which are considered fundamental to understanding Qin economic history. ${ }^{49}$ There were also at least two collaborative works devoted to the collection of sources for Qin and Han economic history published in the 1980s. ${ }^{50}$

The abovementioned nine-volume Chinese economic history edited by Lin Ganquan in 1999 is another good example. In his preface to this multivolume work, while acknowledging Marxist theory as the guiding principle, $\mathrm{Wu}$ Chengming 吳承明 (1917-2011) also emphasized the significance of an empirical approach to conducting historical studies. ${ }^{51}$ Although some Chinese Marxist key concepts appear repeatedly throughout the volume devoted to the Qin and Han periods, it basically outlines the scope of Qin and Han economic history in modern Chinese scholarship during that time. ${ }^{52}$ It was also able to incorporate younger generation historians such as Wang Zijin 王子今 (b. 1950), Ma Yi 馬怡 (b. 1952) and Yang Zhenhong 楊振紅 (b. 1963), who later became the major scholars in the field, as well as their new

46 Li 1962; Peng 1954; Sun 1995.

47 Chen 1958.

48 Huang 1988.

49 Zhang 2004, which was in fact completed in 1987 as stated by the author in his preface.

$50 \mathrm{Fu}$ and Wang 1982; Xie and Zhou 1985.

51 Lin 1999, 1-7.

52 Apart from the theoretical introduction, the rest of the 21 chapters respectively represent a subfield in Qin and Han economic history, which include: 1. Distribution of population; 2. Land and irrigation; 3. Agriculture; 4. Animal husbandry; 5. Forestry and fishing; 6. Land ownership system; 7. Land management system; 8. Inheritance and trading of land; 9. Handicraft; 10. Relations of production in handicraft; 11. Commerce and cities; 12. Prices of commodities; 13. Currencies; 14. Taxation; 15. Labor service; 16. Fiscal institution; 17. Economic policies of the feudal state; 18 . Transportation; 19. Social classes and their statuses and assets; 20. Consumption by different classes; and 21. Economies of ethnic minorities. 
findings in the writing of Qin and Han economic history. ${ }^{53}$ As will be addressed in the final section, the revival of this empirical approach has also benefited from the discoveries of ancient manuscripts in recent decades.

\section{Food and Commodities Semimonthly and the Development of Early Chinese Economic History in Taiwan and Hong Kong}

Already in the 1930s, one of the active participants in the 'Chinese social history controversy,' Tao Xisheng 陶希聖 (1899-1988) had questioned the Marxist interpretation of Chinese history. Dissatisfied with the trending approach which mechanically applied Marxist 'formula' to study Chinese history, Tao founded the Food and Commodities Semimonthly in 1934. Although this semimonthly journal lasted for only two years and seven months due to the Japanese invasion in 1937, it initiated another trend of socioeconomic historical studies which advocated a more evidencebased research approach. The influence of the Food and Commodities Semimonthly was more apparent in Taiwan 臺灣 and Hong Kong 香港 after 1949 when Tao Xisheng and one of his major students at the Peking University 北京大學, Quan Hansheng 全漢昇 (1912-2001), retreated to Taiwan with the Nationalist government. ${ }^{54}$ The journal resumed publication in 1971 in Taiwan on a monthly basis and lasted for another 17 years, during which it met with the new trend in Taiwan which emphasized using social science methods in the study of socioeconomic history. The development of the studies of Qin and Han economic history in Taiwan and Hong Kong after 1949 can only be fully understood within this context.

Despite being a Nationalist, Tao Xisheng was also interested in the Marxist economic model. ${ }^{55}$ After participating in a few years of intense debate on the application of Marxist theory to Chinese history, Tao felt satiated by the endless discussions

53 For example, the volume adopts Ma Yi's view that the enrollment of labor service under the Qin had changed from being based on a person's height to his age in 231 BCE. This argument provides a better way to understand the conflicting records on the age of enrollment seen in transmitted and excavated texts (Lin 1999, 701-708).

54 This does not mean that Tao and his journal had left no influence in mainland China. Another major student of Tao at the Peking University in the 1930s was He Ziquan 何茲全 (1911-2011) who had several articles published in the journal. He had studied and worked at Columbia University and Johns Hopkins University in the late 1940s but decided to return to mainland China in 1950. He later became one of the major scholars focusing on the socioeconomic history of China at the Beijing Normal University 北京師範大學, where he had trained a number of scholars including Hou Xudong 侯旭東 (b. 1968) who is now the head of the Department of History at Tsing Hua University 清華大學.

55 Dirlik calls him “a Guomindang Marxist” (1996, 236). 
of the Marxist approach and returned to more evidence-based methods. ${ }^{56}$ In his "Editorial" to the first issue of the Food and Commodities Semimonthly, Tao stated clearly that the purpose of founding this journal was to provide a platform for scholars who were engaged in Chinese economic and social history to share their thoughts and methodologies and to present the questions and sources they had collected. He claimed that it was dangerous to treat a methodology (by which he meant the Marxist model) as a conclusion and he would rather concentrate on collecting historical sources. ${ }^{57}$ A typical example of this approach is Ma Feibai's 馬非百 (1896-1984) Sources for Qin and Han Economic History (Qin Han jingjishi ziliao 秦漢經濟史資料), which was serialized in seven different issues of the journal, collecting sources for the history of handicraft, commerce, agriculture, currency system, population and land, slavery system, and taxation system during the Qin and Han periods. ${ }^{58}$ Yet this does not mean that the journal neglected the importance of methodologies in studying economic history. In fact, Chinese translations of Western and Japanese work on social science and historical studies constituted a significant portion of this journal. ${ }^{59}$ In addition, the journal did not entirely exclude articles which were engaged in the debate on the periodization of Chinese history. ${ }^{60}$

Whereas most submissions to the Reading Magazine emphasized the backwardness during the imperial period of China (referred to as the feudal stage in the Marxist model, see above), articles published in the Food and Commodities Semimonthly covered different eras of imperial China and demonstrated the historical changes throughout the imperial period. ${ }^{61}$ From 1934 to 1937, 23 articles (including two Chinese translations of Japanese works) focusing on the Qin and Han periods, covering aspects such as fiscal institutions, slavery, taxation, land system, currencies, irrigation, and land clearing, were published in the journal. These articles represented a more evidence-based approach compared to the Marxist conceptualized treatment of Qin and Han economy in the 1930s. It should be mentioned that the influence of this journal had also spread to Japan. Tao had claimed that the Japanese market accounted for about 60 percent of the sales for each issue of the journal. ${ }^{62}$

56 Liang 2003, 300-310.

57 Shihuo banyuekan 1.1 (1934). Such a research focus corresponds to that advocated by Fu Sinian 傅斯年 (1896-1950), the founder of the Institute of History and Philology, Academia Sinica 中央研究院歷史語言研究所. Fu had famously stated that: “[we must] go all the way to Heaven above and Yellow Spring below, using our hands and feet, to search out the stuff of history" 上窮碧落下黃泉, 動手動腳找東西 (Wang 2000, 77). This statement was likely inspired by one made by G. M. Trevelyan (1876-1962): “Collect the facts of the French Revolution! You must go down to Hell and up to Heaven to fetch them" (Xu 2003, 245).

58 In Shihuo banyuekan 2.8 (1935); 2.10 (1935); 3.1 (1935); 3.2 (1935); 3.3 (1936); 3.8 (1936); 3.9 (1936). 59 See the index in Shihuo banyuekan 6.1 (1937).

60 For example, He Ziquan had at least two articles elaborating his thoughts on the feudal society during the Wei and Jin periods published in the journal from 1934 to 1936 (He 2006, 2-3).

61 Liang 2003, 324-326.

62 Tao Xisheng's "Editorial” in Shihuo yuekan 1.1 (1971). For the influence of this journal in Japan, see also Yamada 1993, 18; Kakinuma 2011, 5. 
It is also worth mentioning that the Food and Commodities Semimonthly offered a platform for junior scholars, most of whom were actually Tao's students during that time, to share their new thoughts on economic history. Among Tao's students in the 1930s, Quan Hansheng, who taught in Taiwan and Hong Kong after 1949, later became a prominent figure in the studies of Chinese economic history. Adopting Bruno Hildebrand's (1812-1878) distinction of economic phases, Quan had famously argued that China entered into the phase of natural economy along with the collapse of the Han Empire. He attributed the destruction of Han money economy to the economic damage caused by the collapse of the empire and the remarkable decrease in the supply of copper for the production of coins. Regarding the decrease in the supply of copper, Quan added that the importation of Buddhism from India during the Eastern Han period had caused the consumption of large amounts of copper for the casting of Buddha statues. ${ }^{63}$ As noted by Kakinuma Yōhei, this observation has become one of the influential theories in the modern scholarship of early Chinese monetization. ${ }^{64}$ Since this study mainly focuses on the natural economy during the medieval period of China, Quan did not provide an extensive discussion on the money economy during the Han period. This gap was later filled by Song Xuwu 宋敘五 (1934-2016), one of Quan's students in the New Asia College 新亞書院 in Hong Kong, who offered a comprehensive study of Western Han currencies and its money economy under Quan's guidance in 1971.65

When the journal resumed publication on a monthly basis in Taiwan in 1971, Tao reemphasized the importance of social science methods in the study of socioeconomic history. ${ }^{66}$ This emphasis corresponded to the new trend in Taiwan which was actually initiated by Xu Zhuoyun 許倬雲 (b. 1931) in the 1960s and 1970s. ${ }^{67}$ Originally residing in Wuxi 無錫 in Jiangsu 江蘇 province, Xu Zhuoyun and his family retreated to Taiwan after 1949. He was the first generation of scholars in Taiwan who studied abroad and then returned for teaching. From 1962 to 1972, Xu taught and conducted research at the National University of Taiwan 國立臺灣大學 and the Institute of History and Philology, Academia Sinica, during which he introduced social science methodologies and American University curricula to his Taiwanese colleagues and students. ${ }^{68}$ Educated at the University of Chicago from 1957 to 1962, $\mathrm{Xu}$ was able to study with the major economists and sociologists of the time, such

\footnotetext{
63 Quan 1948.

64 Kakinuma 2011, 7.

65 See Song 2002 for a revised version of this research.

66 Tao Xisheng's “Editorial” in Shihuo yuekan 1.1 (1971). The managing editor was Tao Xisheng's son, Tao Jinsheng 陶晉生 (b. 1933), who received his doctoral degree from Indiana University and returned to Taiwan for teaching from 1969 to 1976. Xu Zhuoyun and Tao Jinsheng were two of the major sources of American social science methodologies in 1960s and 1970s Taiwan (Du 2002, 31). $67 \mathrm{Du} 2002,20-32$.

68 Xu 2011, 299-332.
} 
as Bert F. Hoselitz (1913-1995) and Peter Blau (1918-2002). ${ }^{69}$ In his dissertation, which was published under the title Ancient China in Transition in 1965, he adopted a quantifying approach to analyze the social mobility of different classes of people during the transition from the Spring and Autumn to Warring States periods. ${ }^{70}$ His second book, published in 1980, Han Agriculture, demonstrated the association of intensive farming of small-farm operations with a market economy in Han China. ${ }^{71}$ Both of these studies were considered examples of successful integration of social science and historical studies during that time. Before his return to America in the early 1970s, Xu also helped found the journal Thought and Words (Si yu yan 思與言) in 1963, which to this day is devoted to the studies of social science in Taiwan. ${ }^{72}$ But even more important was Xu's influence on his students and the younger generation of scholars. ${ }^{73}$

As Xu's major student in the 1960-1970s, Du Zhengsheng 杜正勝 (b. 1944) developed his interest in the social and economic history of ancient China. His work on Qin and Han economic history could be best represented by his monumental book, Registered Households and Equal People (bianhu qimin 編戶齊民). ${ }^{74}$ Intrigued by the huge change during the Zhou-Qin transition, Du sought to recover the life of the general public from an institutional perspective. Although Du self-identified this book as social and political history, it actually touched on most of the economic aspects during the transition period, including household registration, military conscription, land tenure system, and agricultural economy. The book title, Registered Households and Equal People, demonstrates Du's major argument: during the ZhouQin transition, the special status and privileges of the nobility were eliminated due to the destruction of the Western Zhou hierarchical system. Being registered on government records, the free people now became equal as subjects of the ruler. The establishment of this household registration system was mainly due to the rising needs of enrolling adult males for military service during the Spring and Autumn and Warring States periods. Given the influence of this book, the term bianhu qimin (registered households and equal people) has now become a common term in referring to the free population during the Qin and Han periods in modern scholarship. This book sets an example for conducting research into social and economic history of ancient China from an institutional perspective.

$69 \mathrm{Xu} 2011,181-186$.

70 Hsu 1965.

71 Hsu 1980.

$72 \mathrm{Xu}$ 2011, 286-297.

73 See Zhang Xiurong's 張秀蓉 article in Xu 2011, 598-607.

$74 \mathrm{Du} 1990$. 


\section{Research on Qin and Han Economic History in Light of the Newly Excavated Ancient Texts}

As introduced in chapter 12.B above, the ancient Chinese texts excavated from the ground in recent years ${ }^{75}$ have reshaped our knowledge of early Chinese economy. Before the significant growth in the discoveries of ancient texts in the 1970s, scholars in the early twentieth century had already noted the importance of newly excavated materials in studying Chinese history. Wang Guowei 王國維 (1877-1927), the renowned scholar at Tsing Hua University, had proposed a research approach called 'method of dual attestation' (erchong zhengju fa 二重證據法), which emphasized using new materials excavated from the ground to examine the transmitted texts. ${ }^{76}$ Following this method, historians such as Chen Zhi in mainland China and Lao Gan 勞翰 (1907-2003) in Taiwan incorporated the Han texts excavated from Juyan 居延 and Dunhuang 敦煌 in the early twentieth century and Han transmitted texts to study the history of the Han dynasty. Their work touched on economic aspects including prices of commodities, coinages, salary grades of frontier officials, slavery, the conscription system, resource management, and economic life on the Han northern frontier. ${ }^{77}$ Yet since the Han wooden documents from Juyan and Dunhuang can only adequately represent the frontier situation, the influence of the unearthed texts in the studies of Qin and Han economic history before the 1970s remained limited.

The 1970s were an important decade in the history of the discoveries of ancient manuscripts in mainland China. There were significant finds almost every year, including the ancient texts excavated from tomb nos. 1 and 3 at Mawangdui 馬王堆 in 1972-1974, tomb nos. 8, 9, 10, 167, 168 and 169 at Fenghuangshan 鳳凰山 in 19731975, fortification sites in the Juyan area in 1974, and tomb no. 11 at Shuhuidi 睡虎地 in $1975 .{ }^{78}$ In response to these findings, the State Administration of Cultural Heritage of the PRC's government organized specialists in groups (the so-called 'research group' [zhengli xiaozu 整理小組]) to preserve and study these manuscripts. As remarked by Li Xueqin 李學勤 (1933-2019), these government-organized research groups provided a shelter for scholars to stay away from the intense political movement during the Cultural Revolution. ${ }^{79}$ Since the reading and transcription of the ancient Chinese graphs required specialized knowledge, the study of Qin and Han

\footnotetext{
$75 \mathrm{Ma}$, ch. 12.B, this volume, offers a more extensive introduction to these findings. This chapter mainly focuses on the changes of concerns and methodologies in Chinese and Japanese historiographies due to these new findings.

76 Wang 1994, 2.

77 Chen 1958; Lao 1976. Note that Chen Zhi is also famous for using artifacts in his examination of transmitted texts.

78 For these findings, see Pian and Duan 2006, and Ma, ch. 12.B, this volume.

79 See Li Xueqin's preface in Pian and Duan 2006, 2.
} 
economic history was not confined to historians. We can observe that paleographers always formed the core of these research groups and they were the first scholars who had access to these ancient manuscripts after the archaeologists in charge of the excavations. Their work demonstrates the significance of paleography in advancing our knowledge of Qin and Han economic history. Frequently, different readings of a single word or term on an excavated text would lead to a variety of interpretations of an economic problem.

The first systematic study of Chinese graphs was finished by an Eastern Han scholar Xu Shen 許慎 (40-121 CE) who compiled the first dictionary in Chinese history, the Explaining the Graphs and Analyzing the Characters (Shuowen jiezi 說文解字). The study of ancient Chinese scripts belonged to the discipline of epigraphy (jinshixue 金石學) during the Song 宋 dynasty (960-1279) and it reached its peak under the Qing evidential research (kaojuxue). At the turn of the twentieth century, the discoveries of Shang 商 oracle bone inscriptions and Han frontier wooden slips and tablets offered firsthand materials for the study of modern paleography (guwenzi xue 古文字學). Starting with Luo Zhenyu 羅振玉 (1866-1940) and Wang Guowei, paleographers stood on the frontline of the studies of ancient Chinese manuscripts. ${ }^{80}$ Nowadays, major research centers on ancient Chinese manuscripts such as those at Wuhan University 武漢大學 (headed by Chen Wei 陳偉 [b. 1955]), Fudan University 復旦大學 (headed by Liu Zhao 劉釗 [b. 1959]) and Tsinghua University (formerly headed by Li Xueqin) ${ }^{81}$ are all under the leadership of renowned scholars specialized in paleography.

A number of new questions and issues related to Qin and Han economic history were raised by these specialists. For example, according to the records in the Liye 里耶 Qin wooden tablets, Li Xueqin argued that the term tuli 徒隸 (laborer-servants), which represents the Qin major governmental labor force, refers to three types of forced laborers: bond servants and bondwomen (lichenqie 隸臣妾), wall-builders and grain-pounders (chengdan chong 城旦春), and gatherers of firewood for the spirits and sifters of white grain (guixin baican 鬼薪白粲). Li’s observation once again brought scholarly attention to the discussion of the nature and composition of forced labor during the Qin period. Examining the inscriptions on Juyan and Dunhuang wooden slips, seals, and roof tiles, another renowned scholar Qiu Xigui 荹錫圭 (b. 1935) has carefully recovered the system of Qin and Han government-organized agricultural production. ${ }^{82}$

As the newly excavated texts are usually held by different academic institutions across mainland China, only a small number of scholars have direct access to the original materials before their full publication. Scholars who are not included in the research group normally need to wait for a long time to see the full publication of

80 Luo and Wang 1993.

$81 \mathrm{Li}$ passed away in 2019 when I was in the middle of revising this chapter.

82 Li 2003; Qiu 1997. 
the materials. For example, the full publication of the legal texts found in tomb no. 247 at Zhangjiashan 張家山, which were originally excavated in 1983, appeared only in 2001. Another example is the Han wooden documents excavated from Jianshui 肩水 golden pass in Ejina 額濟納 River valley in 1974, which were finally published between 2011 and 2016. ${ }^{83}$ Scholars who have no direct access to the original materials have to develop their own advantages based on their historiographical traditions to study these manuscripts.

Initiated by Mori Shikazō 森鹿三 (1906-1980) at the Kyoto University in 1951, Japanese scholars formed long-term reading seminars to study these excavated ancient manuscripts. The participants of the reading seminar on Juyan wooden slips and tablets at the Kyoto University in the 1950s-60s included Fujieda Akira 藤枝晃 (1911-1998), Ōba Osamu 大庭脩 (1927-2002), Nagata Hidemasa 永田英正 (b. 1933) and British scholar Michael Loewe (b. 1922), all of whom later became authorities in the field. Differently from their contemporary Chinese colleagues (such as Lao Gan), who mainly focused on the written content of the excavated texts and used them to examine the transmitted texts, the Kyoto reading seminar led by Mori Shikazō paid particular attention to the excavation locations and material features of these texts. As noted by Fujieda Akira, this research approach was inspired by Japanese 'ancient manuscript studies' (komonjogaku 古文書学). ${ }^{84}$

A large number of ancient manuscripts is preserved in Japan, especially those from the seventeenth century onward. Japanese ancient manuscript studies emphasize the close examination of the original materials, including aspects such as preservation status, appearance, handwritings, and written formats of the manuscripts. Due to this research emphasis, Momiyama Akira 籵山明 (b. 1953) claims that Japanese ancient manuscript studies could therefore be identified as a sub-branch of historical studies, museum studies, or even field studies. ${ }^{85}$ Without direct access to the original materials, the first and second generations of Japanese scholars of the Juyan wooden manuscripts examined the excavation locations, written content and material features of these manuscripts based on the archaeological report. ${ }^{86}$ Using this method, Nagata Hidemasa categorized and identified different types of Han frontier account books and recovered the terminologies and written formats seen in these account books. ${ }^{87}$ Following this research emphasis, later Japanese scholars such as Tomiya Itaru 冨谷至 (b. 1952) and Momiyama Akira kept paying attention to the material features of the unearthed ancient texts, which was often neglected by

\footnotetext{
83 The delay in publication of the excavated texts appears to have greatly improved since the late 1990s. But there are still some materials which were excavated more than 30 years ago but still have not yet been fully published. For example, scholars are still waiting for the full publication of the legal texts excavated from tomb no. 336 at Zhangjiashan in the 1980s.

84 See Fujieda Akira's preface in Nagata 1989.

$85 \mathrm{Su}$ and Chen 2017.

86 Michael Loewe's foreword in Ōba 1993.

87 Nagata 1989.
} 
their contemporary Chinese colleagues. ${ }^{88}$ Examining the notches carved on the Juyan and Dunhuang wooden tallies held by the Academia Sinica in Taiwan and the British Museum in the United Kingdom, Momiyama Akira achieved groundbreaking research results in 1995. He successfully deciphered the numerical meaning represented by different shapes of these notches, which explored the administrative and economic messages hidden in the material features of these manuscripts. ${ }^{89}$

The reading seminar tradition and the insights drawn from Japanese ancient manuscript studies have now become an advantage for Japanese scholars who are engaged in the studies of excavated Chinese manuscripts. Much individual research is actually based on the collaborative work of the reading seminars. ${ }^{90}$ The reading seminar tradition also offers a chance for graduate students and junior scholars to study with the senior scholars in the field. In response to the rapid increase of unearthed ancient manuscripts, it appears that scholars in mainland China, Taiwan, and Hong Kong have started to adopt this reading seminar tradition. For example, responding to the call by Xing Yitian in 2005, scholars and graduate students in Taiwan formed a reading seminar to study the legal texts excavated from tomb no. 247 at Zhangjiashan once every month. In Beijing, under the guidance of Ma Yi and Zhang Rongqiang 張榮強 (b. 1973), since 2008 graduate students and junior scholars at various academic institutes have gathered together to study the newly excavated texts. They have already finished reading the Juyan materials excavated in the 1970s. Due to the new findings from the Wuyi square 五一廣場 in Changsha 長沙, scholars and graduate students at the Department of History at the Chinese University of Hong Kong have recently formed a new reading seminar under the direction of Li Mingzhao 黎明釗 (b. 1956). These reading seminars emphasize cross-checking of the writings of the original materials on the photos against the transcriptions provided in the archaeological reports and paying attention to the preservation status and material features of the ancient Chinese manuscripts. It can be expected

88 Xing Yitian 邢義田 (b. 1947) is one of the few scholars who has paid enough attention to the material features of ancient Chinese manuscripts. This is probably due to his comprehensive training of Roman epigraphy and history at the University of Hawai'i with Michael P. Speidel (b. 1937); e.g., Xing 2011, 1-50. Since the discovery of the meaning of the lines carved on the verso side of bamboo manuscripts by Sun Peiyang 孫沛陽 in 2011, Chinese scholars started to put significantly more energy into the study of the materiality of ancient manuscripts, Sun 2011.

89 For a revised version of this study, see Momiyama 2015, 17-61.

90 There are now at least two active reading seminars of excavated ancient Chinese texts in Japan which are respectively led by Miyake Kiyoshi 宮宅潔 (b. 1969) at the Kyoto University and A. H. Hafner 陶安あんど (b. 1968) at the Meiji University 明治大学. Some of the research results of the reading seminar participants are now available on their official websites. See Shin dai shutsudo moji shiryō no kenkyū 秦代出土文字史料の研究: http://www.shindai.zinbun.kyoto-u.ac.jp/index.html; Chūgoku kodai kan doku no ōdan ryōiki teki kenkyū 中国古代簡牘の横断領域的研究: http:// www.aa.tufs.ac.jp/users/Ejina/contempory.html. 
that these reading seminars will be the places where many new issues and problems in the studies of Qin and Han economic history are raised in the future. ${ }^{91}$

\section{Conclusion}

The discussion above contextualized the writing of Qin and Han economic history in the development of modern Chinese and Japanese historiographies. The cultural interaction between China and Japan can be traced back to the third century when Japan was still under the formation process of an early state. ${ }^{92}$ But this sort of interaction was not equal as Japan always played the role of cultural receiver while China stood as the source of civilization. This situation completely changed in the late nineteenth century when Japan defeated China during the Sino-Japanese War. The shift in intellectual and cultural exchange between China and Japan also changed the ways they viewed Chinese history. The establishment of tōyoshi as a new discipline in Japan and the revolution of traditional Chinese historiography were direct responses to such changes. As discussed above, research into Qin and Han economies in mainland China, Taiwan, Hong Kong, and Japan then followed different paths in the last century as responses to the political and intellectual changes. During the Cultural Revolution, scholars in mainland China were isolated from the outside world due to intense political movement. The direct interaction between scholars in mainland China and Japan gradually resumed when the PRC's government changed their focus on economy rather than politics from the late 1970s onward. We can observe that the intellectual and cultural exchange between China and Japan in recent years no longer flows in one direction, neither merely from China to Japan nor from Japan to China. Chinese and Japanese historians are able to exchange their thoughts and methodologies on Qin and Han economies while developing their own advantages based on their historiographical traditions.

\section{References}

Chen Guowei 沈國威. 2007. “Shidai de zhuanxing yu Riben tujing” 時代的轉型與日本途徑. In Wang Fansen王汎森 (ed.), Zhongguo jindai sixiang shi de zhuanxing shidai 中國近代思 想史的轉型時代, 241-270. Taipei: Lianjing chuban shiye gufen youxian gongsi.

Chen Zhi 陳直. 1958. Liang Han jingji shiliao luncong 兩漢經濟史料論丵. Xi'an: Shanxi renmin chubanshe.

91 The study of Chinese excavated texts may be usefully compared to the first 100 years of Greek papyrology where an equally strong collaborative editorial energy, and historical expertise, went into the publication of the vast material. See von Reden, ch. 8.C, this volume; Keenan 2009.

92 Piggott 1997. 
Dirlik, A. 1978. Revolution and history: The origins of Marxist historiography in China, 1919-1937. Berkeley, CA: University of California Press.

-. 1996. "Social formations in representations of the past: The case of 'feudalism' in twentiethcentury Chinese historiography." Review (Fernand Braudel Center) 19.3, 227-267.

Du Zhengsheng 杜正勝 (= Tu Cheng-sheng). 1990. Bianhu qimin: Chuantong zhengzhi shehui jiegou zhi xingcheng 編戶齊民: 傳統政治社會結構之形成. Taipei: Lianjing chuban shiye gongsi.

-. 2002. “Xin shixue zhi lu: Jian lun Taiwan wushi nian lai de shixue fazhan” 新史學之路: 兼論臺灣五十年來的史學發展. Xin shixue 新史學 13, 21-42.

Egami Namio 江上波夫. 2015. Jin dai Riben hanxue jia: Dongyang xue de xipu di yi ji 近代日本 漢學家: 東洋學的系譜・第一集. Lin Qingzhang 林慶彰 (trans.). Taipei: Wanjuan lou.

Elman, B. 2011. "Early modern or late imperial philology? The crisis of classical learning in eighteenth century China." Frontiers of History in China. 6.1, 3-25.

Fu Zhufu 傅築夫. 1981-1989. Zhongguo fengjian shehui jingji shi 中國封建社會經濟史. 5 vols. Beijing: Renmin chubanshe.

Fu Zhufu 傅築夫 and Wang Yuhu 王毓瑚, eds. 1982. Zhongguo jingjishi ziliao: Qin Han Sanguo bian 中國經濟史資料: 秦漢三國編. Beijing: Zhongguo shehui kexue chubanshe.

Gao Mingshi 高明士. 1986. Zhan hou Riben di Zhongguo shi yanjiu 戰後日本的中國史研究. Taipei: Mingwen shuju.

Guo Moruo 郭沫若. 1954. Nuli zhi shidai 奴隸制時代. Beijing: Renmin chubanshe.

Hamaguchi Shigekuni 浜口重国. 1966. Shin Kan Zui Tō shi no kenkyū 秦漢隋唐史の研究. Tokyo: Tōkyō Daigaku Shuppankai.

He Ganzhi 何幹之. 1937. Zhongguo shehuishi wenti lunzhan 中國社會史問題論戰. Shanghai: Shanghai Shenghuo shudian.

Hanshu 漢書. 1962. Composed by Ban Gu 班固 (32-92 CE). Beijing: Zhonghua shuju.

He Ziquan 何茲全. 2006. He Ziquan wen ji. 何茲全文集. 5 vols. Beijing: Zhonghua shuju. Hirose Kunio 広瀬薰雄. 2010. Shin Kan ritsuryō kenkyū 秦漢律令研究. Tokyo: Kyūko Shoin. Hsu, Cho-Yun. 1965. Ancient China in transition: An analysis of social mobility, 722-222 BC. Stanford, CA: Stanford University Press.

-. 1980. Han dynasty China. Vol. 2, Han agriculture: The formation of early Chinese agrarian economy (206 BC-AD 220). J. L. Dull (ed.). Seattle, WA: University of Washington Press.

Huang Jinyan 黃今言. 1988. Qin Han fuyi zhidu yanjiu 秦漢賦役制度研究. Nanchang: Jiangxi jiaoyu chubanshe.

Hulsewé, A. F. P. 1968. "Chinese communist treatment of the origins and the foundation of the Chinese Empire." In A. Feuerwerker (ed.), History in communist China, 96-123. Cambridge, MA: MIT Press.

Kakinuma Yōhei 柿沼陽平. 2011. Chūgoku kodai kahei keizaishi kenkyū 中国古代貨幣経済史研究. Tokyo: Kyuko Shoin.

Katagiri Kazuo. 1982. "The rise and development of Dutch learning (Rangaku 蘭学) in Japan.” Acta Asiatica 42, 1-17.

Katō Shigeshi 加藤繁, trans. 1942. Shiki heijunsho kanjo shokukashi 史記平準書・漢書食貨志. Tokyo: Iwanami Shoten.

-. 1948. Chūgoku keizaishi no kaitaku 中國經濟史の開拓. Tokyo: Ogiku Shoin.

-. 1952-1953. Shina keizaishi kōshō 支那經濟史考證. 2 vols. Tokyo: Toyo Bunko.

-. 1959. Zhongguo jingjishi kaozheng: Di yi juan 中國經濟史考證・第一卷. Wu Jie 吳杰 (trans.). Beijing: Shangwu yinshuguan.

Keenan, J. G. 2009. "The history of the discipline." In R. Bagnall (ed.), The Oxford handbook of papyrology, 59-78. Oxford: Oxford University Press.

Lao Gan 勞翰 (= Lao Kan). 1976. Lao Gan xueshu lunwenji: Jiabian 勞榦學術論文集：甲編. Taipei: Yiwen yinshuguan. 
Li Genpan 李根蟠. 1999. “Ershi shiji de Zhongguo gudai jingji shi yanjiu”二十世紀的中國 古代經濟史研究. Lishi yanjiu 歷史研究, no. 3, 126-150.

Li Jiannong 李劍農. 1962. Xian Qin liang Han jingji shigao 先秦兩漢經濟史稿. Beijing: Zhonghua shuju.

Li Xueqin 李學勤. 2003. “Chudu Liye Qin jian” 初讀里耶秦簡. Wenwu 文物 no. 1, 73-81.

Liang Gengyao 梁庚堯. 2003. “Cong ‘Dushu zazhi’ dao ‘Shihuo’ banyuekan: Zhongguo shehui jingji shi yanjiu de xingqi” 從《讀書雜誌》到《食貨》半月刊: 中國社會經濟史研 究的興起. In Zhou Liangkai 周樑楷 (ed.), Jiewang erbian 結網二編, 285-340. Taipei: Dongda tushu gufen youxian gongsi.

-. 2005. "Lishi wei tingzhi: Cong Zhongguo shehui shi fenqi lunzheng kan Quan Hansheng de Tang Song jingji shi yanjiu” 歷史未停滞: 從中國社會史分期論爭看全漢昇的唐宋經 濟史研究. Taida lishi xuebao 臺大歷史學報 35, 1-53.

Liang Qichao 梁啟超. 1926. Yichou zhongbianyinbingshi wenji 乙丑重編飲冰室文集. Shanghai: Zhonghua shujiu.

Lin Ganquan 林甘泉. 1999. Zhongguo jingji tongshi: Qin Han jingji juan 中國經濟通史: 秦漢經濟卷. Beijing: Jingji ribao chubanshe.

Lu Yaodong 逯耀東. 1979. Zhonggong shixue de fazhan yu yanbian 中共史學的發展與演變. Taipei: Shibao wenhua chuban shiye youxian gongsi.

Luo Zhenyu 羅振玉 and Wang Guowei 王國維. 1993. Liusha zhuijian 流沙墜簡. Beijing: Zhonghua shuju.

Lurie, D. B. 2011. Realms of literacy: Early Japan and the history of writing. Cambridge, MA: Harvard University Asia Center.

Masini, F. 1993. The formation of modern Chinese lexicon and its evolution toward a national language: The period from 1840 to 1898. Berkeley, CA: University of California Project on Linguistic Analysis.

Mehl, M. 2000. “Chinese learning (Kangaku) in Meiji Japan (1868-1912).” History 85, 48-66.

Momiyama Akira 籵山明. 2015. Shin kan shutsudo moji shiryō no kenkyū: keitai, seido, shakai 秦漢出土文字史料の研究：形態・制度・社会. Tokyo: Sobunsha.

Nagata Hidemasa 永田英正. 1989. Kyoen Kankan no kenkyū 居延漢簡の研究. Kyoto: Dohosha. Nishijima Sadao 西嶋定生. 1981. Chūgoku kodai no shakai to Keizai. 中国古代の社会と経済. Tokyo: Tōkyō Daigaku Shuppankai.

-. 1986. "The economic and social history of Former Han." In D. Twitchett and M. Loewe (eds.), The Cambridge history of China. Vol. 1, 545-607. Cambridge: Cambridge University Press.

Ōba Osamu 大庭脩, ed. 1993. Kankan kenkyū no genjō to tenbō 漢簡研究の現状と展望. Suita: Kansai Daigaku Shuppanbu.

Peng Xinwei 彭信威. 1954. Zhongguo huobishi 中國貨幣史. Shanghai: Qunlian chubanshe.

Pian Yuqian 駢宇騫 and Duan Shu'an 段書安. 2006. Ershi shiji chutu jianbo zongshu 二十世紀出土簡帛綜述. Beijing: Wenwu chubanshe.

Piggott, J. R. 1997. The emergence of Japanese kingship. Stanford, CA: Stanford University Press. Qiu Xigui 装錫圭. 1997. “Cong chutu wenzi ziliao kan Qin he Xi Han shidai guanyou nongtian de jingying” 從出土文字資料看秦和西漢時代官有農田的經營. In Zang Zhenhua 㶓振華 (ed.), Zhongguo kaogu xue yu lishi xue zhi zhenghe yanjiu 中國考古學與歷史學之整合研究, 429478. Taipei: Zhongyang yanjiuyuan lishi yuyan yanjiusuo.

Quan Hansheng 全漢昇 (= Chuan Han-Sheng). 1948. “Zhonggu ziran jingji” 中古自然經濟. Zhongyang yanjiuyuan lishi yanjiusuo jikan 中央研究院歷史語言研究所集刊 10, 73-173.

Sahara Yasuo 佐原康夫. 2002. Kandai toshi kikō no kenkyū 漢代都市機構の研究. Tokyo: Kyūko Shoin.

Shigechika Keiju 重近啓樹. 1999. Shin Kan zeieki taikei no kenkyū 秦漢稅役体系の研究. Tokyo: Kyūko Shoin.

Song Xuwu 宋敘五 (= Sung Shee-wu). 2002. Xi Han huobishi 西漢貨幣史. Hong Kong: Chinese University Press. 
Su Junlin 蘇俊林 and Chen Hongyin 陳弘音. 2017. “Riben Dongyang Wenku yanjiuyuan Nishan Ming: Zai jianduxue, guwenshuxue, fazhishi yu Qin Han shi zhijian” 日本東洋文庫研究 員籵山明: 在簡牘學, 古文書學, 法制史與秦漢史之間. Wenhuibao 文匯報. February 3, 2017, W10.

Sun Peiyang 孫沛陽. 2011. “Jiance bei huaxian chutan” 簡冊背劃綫初探. Chutu wenxian yu gu wenzi yanjiu 出土文獻與古文字研究 4, 449-462.

Sun Yutang 孫毓棠. 1995. Sun Yutang xueshu lunwenji 孫毓棠學術論文集. Beijing: Zhonghua shuju.

Swann, N. L. 1950. Food and money in ancient China: The earliest economic history of China to AD 25: Han Shu 24 with related texts, Han Shu 91 and Shih-chi 129. Princeton, NJ: Princeton University Press.

Tanigawa Michiol. 1985. Medieval Chinese society and the local "community." J. A. Fogel (trans.). Berkeley, CA: University of California Press.

Tao Jinsheng 陶晉生, et al., eds. 1971-1988. Shihuo yuekan 食貨月刊. Taipei: Shihuo yuekan she.

Tao Xisheng 陶希聖, ed. 1934-1937. Shihuo banyuekan 食貨半月刊. Peiping: Xin shengming shujiu.

Tian Changwu 田昌五 and Qi Xia 漆俠, eds. 1996. Zhongguo fengjian shehui jingji shi 中國封建社會經濟史. 4 vols. Jinan: Qilu shushe.

Utsunomiya Kiyoyoshi 宇都宮清吉. 1955. Kandai shakai keizaishi kenkyū 漢代社会経済史研究. Tokyo: Kōbundō.

Wang, Fan-sen. 2000. Fu Ssu-nien: A life in Chinese history and politics. Cambridge: Cambridge University Press.

Wang Guowei 王國維. 1994. Gushi xinzheng: Wang Guowei zuihou de jiangyi 古史新證: 王國維最後的講義. Beijing: Qinghua daxue chubanshe.

Wang Lixi 王禮錫 and Lu Jingqing 陸晶清, eds. 1990. Zhongguo shehuishi de lunzhan 中國社會史的論戰. Shanghai: Shanghai shudian.

Wang Qingjia 王晴佳. 2003. “Zhongguo jindai ‘xin shixue’ de Riben beijing: Qing mo de 'shijie geming' he Riben de “wenming shixue” 中國近代「新史學」的日本背景：清末的

「史界革命」和日本的「文明史學」. Taida lishi xuebao 臺大歷史學報 32, 191-236.

Wang, Q. E. (= Wang Qingjia). 2001. Inventing China through history: The May Fourth approach to historiography. Albany, NY: State University of New York Press.

Watanabe Shinichirō 渡邊信一郎. 2010. Chūgoku kodai no zaisei to kokka 中國古代の財政 と國家. Tokyo: Kyūko Shoin.

Wilbur, C. M. 1943. Slavery in China during the Former Han dynasty, 206 BC-AD 25. Chicago, IL: Field Museum of Natural History.

Xie Guihua 謝桂華 and Zhou Nianchang 周年昌, eds. 1985. Qin Han wujia zilao jilu 秦漢物價資料輯錄. In Zhongguo gudai shehui jingjishi ziliao 中國古代社會經濟史資料. Vol. 1. Fuzhou: Fujian renmin chubanshe.

Xing Yitian 邢義田 (= Hsing I-tien). Di bu ai bao: Handai jiandu 地不愛寶：漢代簡牘. Beijing: Zhonghua shuju.

Xu Guansan 許冠三. 2003. Xin shixue jiushi nian 新史學九十年. Changsha: Yuelu shushe.

Xu Zhuoyun 許倬雲 (= Cho-Yun Hsu). 2011. Jiashi, guoshi, tianxiashi: Xu Zhuoyun bashi huigu 家事、國事、天下事: 許倬雲八十回顧. Hong Kong: Chinese University Press.

Yamada Katsuyoshi 山田勝芳. 1993. Shin Kan zaisei shūnyū no kenkyū 秦漢財政収入の研究. Tokyo: Kyuko Shoin.

Zhang Jihai 張繼海. 2006. Han dai chengshi shehui 漢代城市社會. Beijing: Shehui kexue wenxian chubanshe.

Zhang Jinguang 張金光. 2004. Qin zhi yanjiu 秦制研究. Shanghai: Shanghai guji chubanshe.

Zhou Yunxi 周筠溪. 1936. “Xi Han caizheng zhidu zhi yiban” 西漢財政制度之一班. Shihuo banyuekan 食貨半月刊 3.8, 8-36. 